\title{
Iron nutrition in the UK: getting the balance right
}

\author{
Susan J. Fairweather-Tait \\ Institute of Food Research, Norwich NR4 7UA, UK
}

\begin{abstract}
Fe homeostasis is considered in the context of the UK diet, using information on Fe intake and status from the National Diet and Nutrition Surveys. The importance of assessing Fe availability rather than total $\mathrm{Fe}$ intake is discussed. Dietary and host-related factors that determine $\mathrm{Fe}$ bioavailability (Fe utilised for $\mathrm{Hb}$ production) are reviewed using information from single-meal studies. When adaptive responses are taken into consideration, foods associated with higher $\mathrm{Fe}$ status include meat (haem-Fe and the 'meat factor') and fruits and fruit juice (vitamin $\mathrm{C}$ ). Foods that may have a negative impact include dairy products $(\mathrm{Ca})$, high-fibre foods (phytate) and tea and coffee (polyphenols), but the effects are more apparent in groups with marginal $\mathrm{Fe}$ deficiency, such as women of childbearing age. Analysis of dietary intake data on a meal-bymeal basis is needed to predict the influence of changing dietary patterns on Fe nutrition in the UK. Current information suggests that in the UK Fe deficiency is a greater problem than Fe overload.
\end{abstract}

Fe intake and status: Bioavailability of Fe: Fe-deficiency risk: Dietary patterns

Fe plays an essential role in many biochemical reactions, and its ability to accept or donate electrons is central to the redox reactions of oxidative phosphorylation in the respiratory chain. Fe provides a specific binding site for $\mathrm{O}_{2}$ in the haem moiety of $\mathrm{Hb}$ in erythrocytes and myoglobin in muscle. There is also a mobilisable $\mathrm{Fe}$ store of varying size in ferritin, mainly present in the liver. Free Fe can catalyse the formation of free radicals, which may cause damage to proteins and DNA; therefore, the body has evolved complex systems to ensure free Fe cannot exist in vivo. It is transported between different compartments in the body by transferrin, and is supplied to cells by three mechanisms: (1) continuous recycling of Fe from catabolised erythrocytes; (2) newly-absorbed dietary Fe; (3) release of Fe from ferritin stores in the liver (Bothwell et al. 1979). Dietary Fe is absorbed in the mucosal cells of the duodenum and jejunum (for review, see Miret et al. 2003). Haem- and non-haem-Fe are taken up by two independent pathways, but once inside the cell all Fe enters a common pool (Fig. 1). Uptake of Fe into cells is regulated by the synthesis of transferrin receptors on the cell surface that control the rate of flow of $\mathrm{Fe}$ to different tissues according to need.

\section{Iron deficiency and excess}

Fe balance is maintained through changes in the efficiency of absorption whereby absorption is up regulated to redress $\mathrm{Fe}$ deficit. When the functional $\mathrm{Fe}$ compartment is replenished and mobilisable $\mathrm{Fe}$ has accumulated in ferritin stores (represented by a serum ferritin concentration $>60-70 \mu \mathrm{g} / \mathrm{l})$, the quantity of haem- and non-haem-Fe absorbed falls to a level just sufficient to cover basal losses in order to avoid excessive deposition of Fe (Hallberg et al. 1997). Nutritional Fe deficiency arises when the supply of $\mathrm{Fe}$ is insufficient to cover physiological requirements, whereas $\mathrm{Fe}$ overload is either the result of chronic exposure to high levels of $\mathrm{Fe}$, as found in some dietary supplements, or occurs in individuals who lack the normal homeostatic mechanisms that regulate $\mathrm{Fe}$ absorption. Health implications of Fe overload and the role of diet and genotype have been reviewed by Heath \& Fairweather-Tait (2003). Hallberg \& Hulthen (2002) argue that the strong relationships observed between $\mathrm{Fe}$ requirements, bioavailability of dietary Fe and quantity of stored $\mathrm{Fe}$ demonstrate the presence of very effective control mechanisms that prevent the development of Fe overload in healthy individuals, even if the diet is fortified with $\mathrm{Fe}$ 


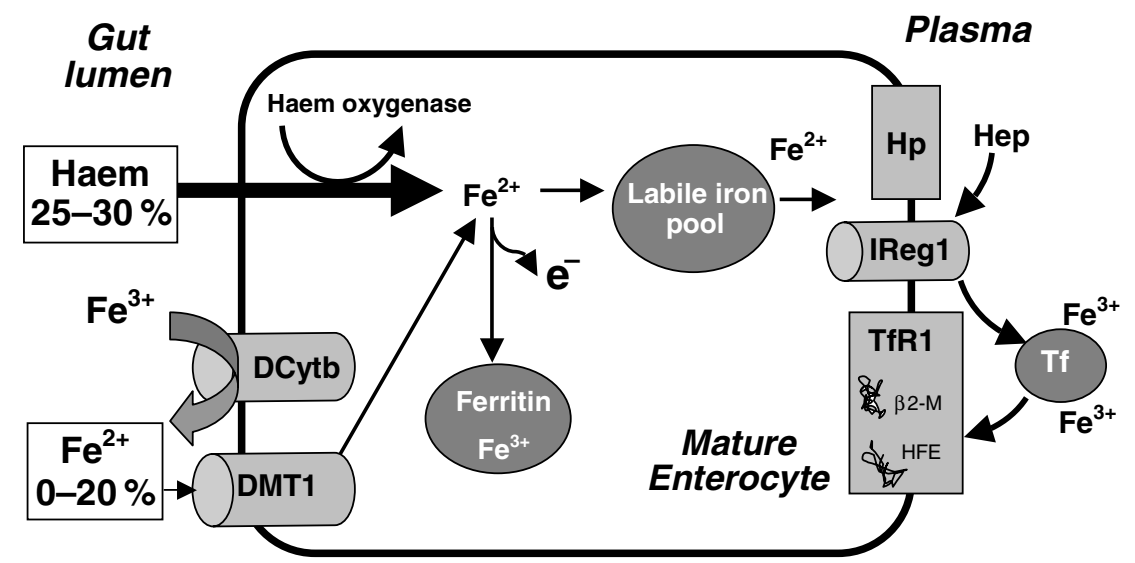

Fig. 1. Schematic diagram to illustrate how iron is absorbed in the mucosal cells of the small intestine. Dcytb, duodenal cytochrome b; DMT1, divalent metal transporter; IReg1, iron-regulated protein 1 (also known as ferroportin 1); Hp, hephaestin; Hep, hepcidin; Tf, transferrin; TfR1, transferrin receptor 1 ; HFE, haemochromatosis protein; $\beta 2-\mathrm{M}, \beta 2-$ microglobulin.

or the meat intake is high. The genetic basis and treatment of $\mathrm{Fe}$-storage diseases, the clinical penetrance of haemochromatosis and the diagnosis and treatment of $\mathrm{Fe}$ deficiency have been reviewed by Beutler et al. (2003).

\section{Measurement of iron status}

A range of biochemical and haematological indices are used for the detection of Fe deficiency and the assessment of Fe status. The extent of Fe deficiency or overload is directly proportional to the size of the Fe compartments in the body. When demand outstrips supply, stores of Fe in ferritin will be mobilised and the body will become progressively $\mathrm{Fe}$ depleted (Fig. 2). Once the storage $\mathrm{Fe}$ compartment is exhausted Fe-deficient erythropoiesis will take place (stage I). Recycling of the functional $\mathrm{Fe}$ compartment (Hb, myoglobin, cytochromes, transport
$\mathrm{Fe}$, etc.) supplies $\mathrm{Fe}$ to the erythrocyte precursors of the bone marrow (stage II) and with a continuing negative $\mathrm{Fe}$ balance, the deficiency will progress to Fe-deficiency anaemia, characterised by the appearance of microcytic hypochromic erythrocytes (stage III).

In population studies, including the UK National Diet and Nutrition Surveys (NDNS), the most-widely-used indices of $\mathrm{Fe}$ status are $\mathrm{Hb}$ concentration, transferrin saturation (TS) and serum ferritin (SF). Cut-off values for Fe deficiency or $\mathrm{Fe}$ overload in different groups are given in Table 1. Detection of early Fe-deficiency anaemia, when the $\mathrm{Hb}$ concentration is only just beginning to fall, is not easy because the cut-off point differs between individuals; normal $\mathrm{Hb}$ distributions vary with gender (Wintrobe, 1981), age (Yip et al. 1984), pregnancy (Yip, 2000), altitude (Tufts et al. 1985), smoking (Van Tiel et al. 2002), season (Lee et al. 1987) and ethnic origin (Pan \& Habicht, 1991).

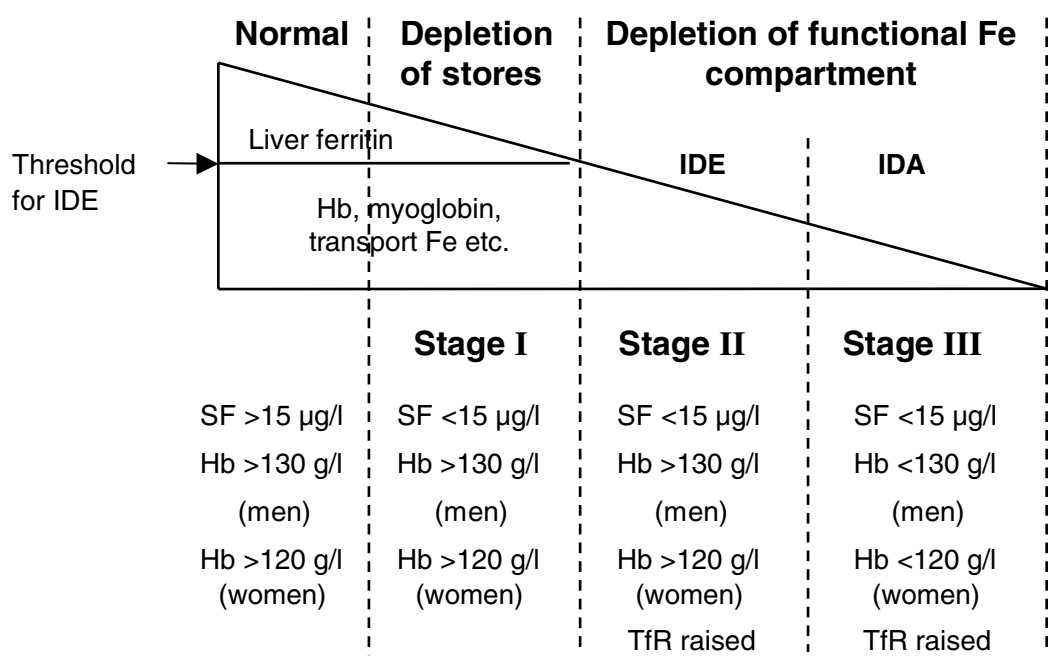

Fig. 2. Stages in the development of iron deficiency. IDE, iron-deficient erythropoiesis; IDA, iron-deficient anaemia; SF, serum ferritin; TfR, transferrin receptor. (Adapted from Suominen et al. 1998.) 
Table 1. Cut-off values for iron deficiency or overload in groups of the UK population studied in National Diet and Nutrition Surveys (NDNS)

(Values used to evaluate NDNS data (Fig. 3) are shown in parentheses; other values are referenced)

\begin{tabular}{cccc}
\hline & Children & $\begin{array}{c}\text { Men } \\
(\geq 15 \text { years })\end{array}$ & $\begin{array}{c}\text { Women } \\
(\geq 15 \text { years })\end{array}$ \\
\hline $\begin{array}{cccc}\text { Fe deficiency } \\
\mathrm{Hb}(\mathrm{g} / \mathrm{l})\end{array}$ & $110-120^{*} \dagger$ & $\begin{array}{c}130 \ddagger \\
(125 ; \text { adult }\end{array}$ & $\begin{array}{c}120 \ddagger \\
(125 ; \text { adult } \\
\end{array}$ \\
& & survey $)$ & survey $)$ \\
$\mathrm{TS}(\%)$ & $10^{*}(15)$ & $15 \S$ & $15 \S$ \\
$\mathrm{SF}(\mu \mathrm{g} / \mathrm{l})$ & $12^{*}(15)$ & $15 \dagger$ & $12 \dagger$ \\
& & $(13 ;$ adult & $(13$, adult; \\
& & survey $)$ & 15$, elderly $)$ \\
Fe overload & & & $>165 \|$ \\
$\mathrm{Hb}(\mathrm{g} / \mathrm{l})$ & & $>180 \|$ & $>150 \dagger$ \\
$\mathrm{SF}(\mu \mathrm{g} / \mathrm{l})$ & & $>200 \dagger$ & $>45 \uparrow$ \\
$\mathrm{TS}(\%)$ & & $>50 \uparrow$ & \\
\hline
\end{tabular}

TS, transferrin saturation; SF, serum ferritin.

${ }^{*}$ Oski (1993).

+World Health Organization/UNICEF/United Nations University (2001).

$\ddagger$ World Health Organization (1972).

§Bates et al. (1997).

Dacie \& Lewis (1995).

Velati et al. (2003).

Fe deficiency without anaemia is generally determined from SF concentration. Phlebotomy studies indicate that $1 \mu \mathrm{g} \mathrm{SF} / 1$ corresponds to about $8 \mathrm{mg}$ storage Fe (Walters et al. 1973), which makes SF the most informative laboratory measure of body Fe. However, because apoferritin is an acute-phase reactant protein, irrespective of changes in $\mathrm{Fe}$ stores, $\mathrm{SF}$ concentration will increase in response to infection and inflammatory processes and can remain elevated for several weeks post infection (Hulthen et al. 1998). It is common practice to measure plasma C-reactive protein or, in the case of NDNS (Finch et al. 1998), $\alpha_{1^{-}}$ antichymotrypsin (Calvin et al. 1988) as markers of infection or inflammation. SF measurements should be calibrated against a reference standard (National Institute for Biological Standards and Control, Potters Bar, Herts.) (World Health Organization/UNICEF/United Nations University, 2001) and at least three independent measurements are required to allow for day-to-day variation (Borel et al. 1992). TS (serum Fe/total Fe-binding capacity) measurements are subject to diurnal variation (Guillygomarc'h et al. 2003), but are considered useful as a first screening step for the inherited Fe-overload disorder, hereditary haemochromatosis.

The detection of Fe-deficient erythropoiesis is a key measure, as it identifies marginal Fe deficiency and is characterised by elevated levels of $\mathrm{Zn}$ protoporphyrin. The final reaction in haem biosynthesis is the chelation of $\mathrm{Fe}$ with protoporphyrin, but when $\mathrm{Fe}$ is not available $\mathrm{Zn}$ is used as an alternative metal substrate for ferrochetalase. The measurement and diagnostic use of $\mathrm{Zn}$ protoporphyrin has been reviewed in detail by Labbe et al. (1999). Serum transferrin receptors also increase in the early stages of Fe deficiency and are not affected by infection or inflammation, and do not vary with age, gender or pregnancy
(Beutler et al. 2003). However, the diagnostic usefulness of the serum transferrin receptors is limited because of the divergent values obtained from different assays and the lack of an international standard. The serum transferrin receptors: $\log \mathrm{SF}$ index has been proposed for identifying subclinical Fe deficiency (Punnonen et al. 1997). More recently, Cook et al. (2003) used National Health and Nutrition Examination Survey III data to calculate body Fe based on serum transferrin receptors:SF; the use of this ratio was validated by means of an Fe-supplementation trial in Jamaica and an Fe-fortification study in Vietnam. Quantitative estimates of body Fe are useful for epidemiological studies examining Fe nutrition and for assessing the efficacy of intervention trials to improve Fe status. However, as discussed earlier, methods that rely on SF may be confounded by infection or inflammation. The limitations of each index in terms of specificity and sensitivity have led to the adoption of multiple indices for the detection of $\mathrm{Fe}$ deficiency in populations, e.g. National Health and Nutrition Examination Survey, although this approach underestimates Fe deficiency. A useful combination would be $\mathrm{Hb}$, serum transferrin receptors and SF to reflect functional impairment, tissue depletion and storage $\mathrm{Fe}$ respectively.

\section{Iron status of subgroups in the UK population}

Data from NDNS provide information on the Fe status of the UK population, including the elderly (age $\geq 65$ years; Finch et al. 1998), the young (age 4-18 years; Gregory et al. 2000) and adults (Ruston et al. 2004). Fe deficiency is more common in women than men (Fig. 3), particularly in the 15-18 years age-range. In adults Fe-deficiency anaemia is observed in $3 \%$ of men and $8 \%$ of women, and low $\mathrm{Fe}$ stores in $2 \%$ of men and $11 \%$ of women. In the survey of the elderly the large number of men and women with a low $\mathrm{Hb}$ concentration is not consistent with the SF

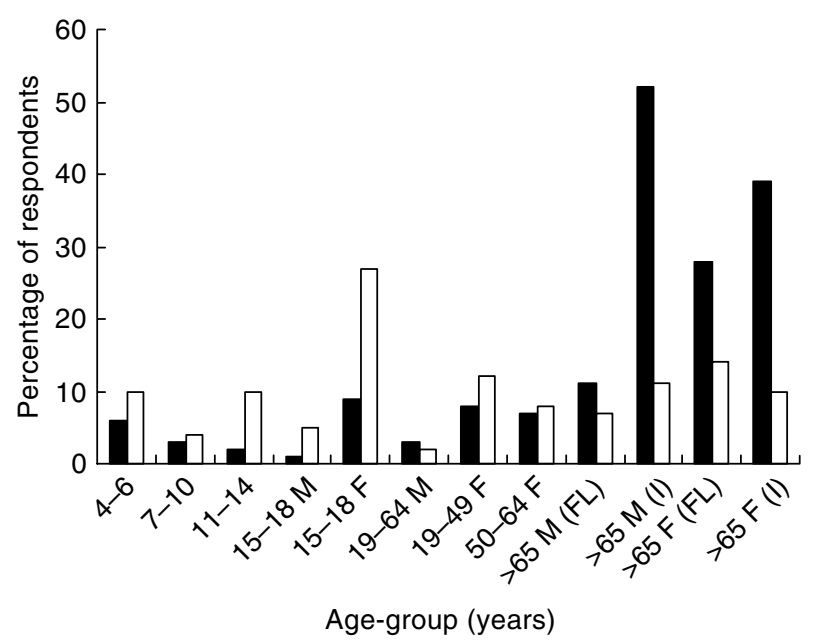

Fig. 3. Iron deficiency in the UK: percentage of individuals participating in the National Diet and Nutrition Surveys who fall below the suggested cut-off value (see Table 1). ( $\mathbf{\square})$, Low $\mathrm{Hb}$; $(\square)$, low serum ferritin. M, male; F, female; FL, free-living; I, institutionalised. 
Table 2. Upper 2.5 percentiles for serum ferritin and transferrin saturation in the National Diet and Nutrition Survey of adults in 2000-1 and of the elderly (free-living) in 1994-5

\begin{tabular}{lcc}
\hline $\begin{array}{l}\text { Age-group } \\
\text { (years) }\end{array}$ & $\begin{array}{c}\text { Serum ferritin } \\
(\mu \mathrm{g} / \mathrm{l})\end{array}$ & $\begin{array}{c}\text { Transferrin saturation } \\
(\%)\end{array}$ \\
\hline Men & & \\
$25-34$ & 201 & $50 \cdot 3$ \\
$35-49$ & 512 & $50 \cdot 8$ \\
$50-64$ & 505 & $51 \cdot 3$ \\
$65-74$ & 384 & $50 \cdot 8$ \\
$75-84$ & 408 & $55 \cdot 6$ \\
$\geq 85$ & 651 & $52 \cdot 5$ \\
Women & & \\
$50-64$ & 232 & $52 \cdot 3$ \\
$65-74$ & 258 & $48 \cdot 4$ \\
$75-84$ & 352 & $43 \cdot 2$ \\
$\geq 85$ & 295 & $43 \cdot 7$ \\
\hline
\end{tabular}

data, which probably means that the cut-off values used to define deficiency are inappropriate.

It is not possible to quantify Fe overload from the SF and TS data, but according to the upper 2.5 percentile values for SF and percentage TS for adults and the elderly (Table 2) Fe stores are higher in men than in women. The upper 2.5 percentile is above the normal range for SF in both men and women, but the TS values are very close to the upper limit, with the exception of 50-64-year-old women. The lack of consistency between the two measures raises questions about the appropriateness of the cut-off values. Further analysis of the data and more definitive tests of body $\mathrm{Fe}$ content are required to assess the extent of $\mathrm{Fe}$ overload.

\section{Iron intake}

According to data from the National Food Survey (http:// statistics.defra.gov.uk/esg/publications/nfs/default.asp) $\mathrm{Fe}$ intake in the UK has fallen steadily from a mean of approximately $14 \mathrm{mg} / \mathrm{d}$ in 1965 to $10 \mathrm{mg} / \mathrm{d}$ in the $1990 \mathrm{~s}$, at which level it has remained relatively constant. Fe intake mirrors energy intake, indicating that the Fe density of the UK diet has not changed but the sources of $\mathrm{Fe}$ have changed. Prynne et al. (1999) compared the food and nutrient intake of a national sample of 4-year-old children in 1950 with that in the 1990s. In 1950 bread and red meat were the most important sources of Fe, whereas in 1992-3, bread consumption had fallen dramatically and much of the Fe was provided by breakfast cereals and other cerealbased products such as biscuits; also, the contribution made by meat and eggs had fallen (Fig. 4). There are no marked differences in total Fe intake in the 1986-7 and 2000-1 NDNS, which endorses the findings of the National Food Survey. However, total Fe intake is a poor predictor of $\mathrm{Fe}$ status, as exemplified by results from a recent study on women of childbearing age in the UK, in which Fe intakes were analysed from a $7 \mathrm{~d}$ duplicate diet (Harvey LJ, Armah C, Dainty J, Foxall R, Lewis J, Langford $\mathrm{N}$ and Fairweather-Tait SJ, unpublished results). Fig. 5 illustrates the lack of relationship between mean daily $\mathrm{Fe}$ intake and $\mathrm{Fe}$ stores assessed from SF concentration.

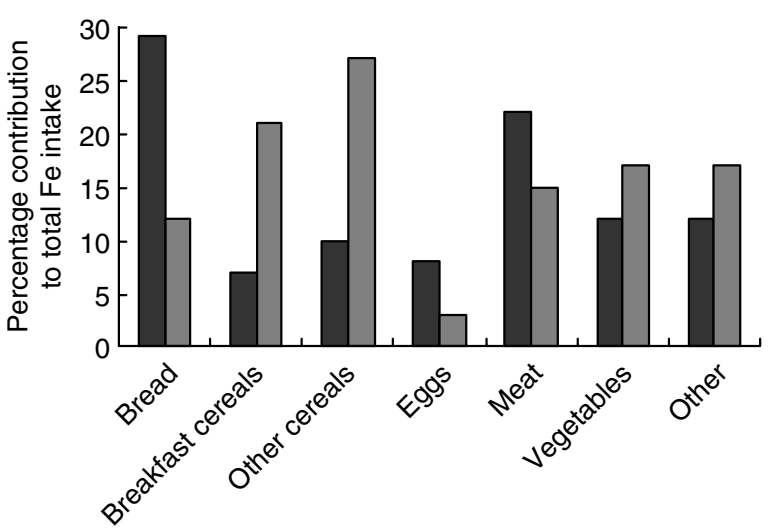

Fig. 4. Contribution of food groups to the iron intake of children aged 4 years in national studies in 1950 ( $n$ 4599) and 1992-3 ( $n$ 493). ( $\square$ ), 1950; ( $\square$ ), 1992-3. (From Prynne et al. 1999.)

The reason is that $\mathrm{Fe}$ absorption depends on both the availability for absorption and the absorptive capacity of the intestinal cells.

\section{Iron bioavailability}

The proportion of an ingested nutrient that is utilised for normal body function is a measure of its bioavailability. In normal individuals approximately $80 \%$ of absorbed Fe is used for $\mathrm{Hb}$ synthesis (Finch et al. 1970), thus Fe absorption can be used to assess bioavailability. Fe-deficiency anaemia increases Fe utilisation (Beshara et al. 2003), therefore it is important to characterise $\mathrm{Fe}$ status when assessing Fe bioavailability. There are a number of dietary and physiological factors that are known to influence $\mathrm{Fe}$ absorption (Table 3).

The primary role of host-related variables is the maintenance of $\mathrm{Fe}$ homeostasis by ensuring an appropriate response to increased or decreased requirements for Fe. Thus, absorption is up regulated with Fe depletion (Baynes et al. 1987), until the body has accumulated sufficient

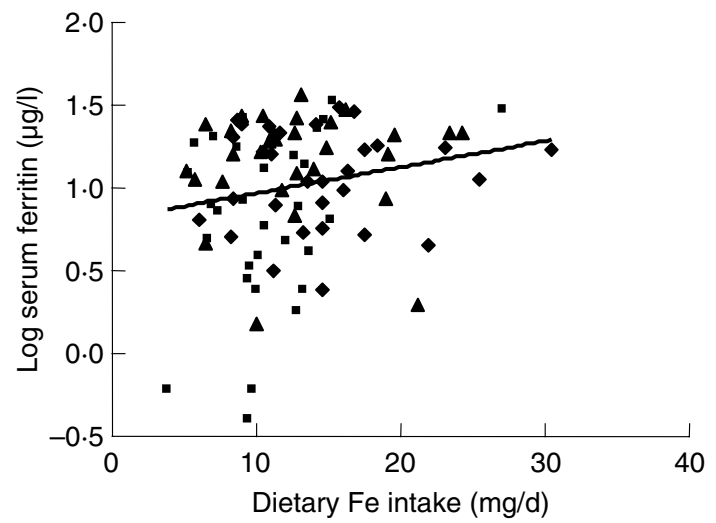

Fig. 5. Relationship between mean iron intake $(\mathrm{mg} / \mathrm{d})$ and iron stores (serum ferritin $\mu \mathrm{g} / \mathrm{l}$ ) in UK women of childbearing age consuming different diets. ( $\mathbf{\square})$, Red meat; $(\mathbf{\Lambda})$, poultry and fish; $(\bullet)$, vegetarian; $(-)$, all data. $R^{2} 0.0384$. (From Harvey LJ, Armah C, Dainty J, Foxall R, Lewis J, Langford N and Fairweather-Tait SJ, unpublished results.) 
Table 3. Factors that affect iron absorption

\begin{tabular}{ll}
\hline Dietary & \multicolumn{1}{c}{ Host-related } \\
\hline Enhancing & Enhancing \\
Meat, poultry and fish & Fe-deficiency anaemia \\
Vitamin C & Low body stores \\
Alcohol & Gastric acid \\
Inhibitory & Bile and pancreatic secretions \\
Phytate $\left(\mathrm{IP}_{6}\right)$ and inositol & Hypoxia (high altitude) \\
phosphates $\mathrm{IP}_{3}-\mathrm{IP}_{5}$ & Pregnancy \\
Polyphenols and other & Increased erythropoiesis \\
flavonoids & (e.g. after blood loss) \\
Tea and coffee & Homozygosity for C282Y \\
Eggs & mutation of HFE gene \\
Ca and dairy products & Inhibitory \\
Other transition metals & High body stores \\
(Zn, Cu) & Previous high intake of iron \\
& Rapid gastric emptying \\
\hline
\end{tabular}

$\mathrm{IP}_{6}, \mathrm{IP}_{3}, \mathrm{IP}_{5}$, inositol hexa-, tri- and pentaphosphates respectively.

storage Fe (Hallberg et al. 1997), and with increased erythropoietic activity (Skikne \& Cook, 1992) resulting from blood loss or tissue hypoxia (Skikne \& Baynes, 1994). Conversely, absorption is down regulated when stores are high or following a large dose of Fe, sometimes referred to as the 'mucosal block' (O'Neil-Cutting \& Crosby, 1987). Pregnancy is associated with a progressively higher efficiency of $\mathrm{Fe}$ absorption (Barrett et al. 1994), and factorial estimates indicate that absorption increases during periods of rapid growth in children (Taylor et al. 1988).

Regulation of $\mathrm{Fe}$ absorption is affected by mutations in the haemochromatosis protein gene; $\mathrm{C} 282 \mathrm{Y}$ homozygotes are at risk of developing hereditary haemochromatosis, although clinical penetrance is low (Waalen et al. 2002). The C282Y mutation is relatively common in Caucasian populations, particularly in those of Celtic origin, with a reported frequency as high as $17 \%$ in Northern Ireland (Murphy et al. 1998). C282Y heterozygous men and women have slightly elevated TS, but SF concentration does not appear to be raised (Burt et al. 1998; Jackson et al. 2001). Relatives of patients with haemochromatosis who carry the $\mathrm{C} 282 \mathrm{Y}$ mutation and wild-type controls have been reported to absorb similar quantities of $\mathrm{Fe}$ from a hamburger meal, suggesting that heterozygotes have similar regulatory mechanisms (Lynch et al. 1989), but when given $20 \mathrm{mg} \mathrm{Fe}$ (as ferrous sulphate) plus $100 \mathrm{mg}$ vitamin $\mathrm{C}$, absorption is markedly higher. However, a recent study has shown no difference between male heterozygotes and wild-type controls in the absorption of $\mathrm{Fe}$ from Fe-fortified cereals or from a diet high in available Fe (Roe MA, Heath A-L, Oyston SL, Macron C, Hoogewer J, Foxall R, Dainty J, Majsate-Newman G, Willis G and Fairweather-Tait SJ, unpublished results).

Digestion plays a key role in determining how much $\mathrm{Fe}$ is released from the food matrix and subsequently made available for absorption. Gastric acid and the rate of stomach emptying affect Fe solubilisation (Bezwoda et al. 1978), and amino acids, peptides and mucoproteins produced by pancreatic enzymes and bile are believed to act as absorption-promoting ligands (Jacobs \& Miles, 1970). Day-to-day variability in the efficiency of Fe absorption
(Kuhn et al. 1968) has not been widely reported, as it is technically difficult to measure. Variation presumably occurs because of fluctuations in physiological factors that determine $\mathrm{Fe}$ availability, and/or short-term mechanisms that maintain $\mathrm{Fe}$ homeostasis emanating from the mucosal cells of the small intestine (Frazer et al. 2003) as opposed to the systemic longer-term control associated with body Fe status (Leong \& Lonnerdal, 2004). Multiple-dosing protocols are generally adopted to compensate for meal-tomeal variations in absorption (Fox et al. 1998) or to enable absorption from a whole diet to be measured (Minihane \& Fairweather-Tait, 1998).

Dietary components affect Fe availability by means of chemical reactions in the stomach and lumen of the small intestine. For example, ascorbic acid reduces $\mathrm{Fe}^{3+}$ to the more soluble $\mathrm{Fe}^{2+}$, which is the form required for transport into mucosal cells (Fig. 1). It also binds Fe, thus preventing it forming a complex with phytate or tannin that renders the $\mathrm{Fe}$ unavailable to divalent metal transporter 1. The relative binding affinity for $\mathrm{Fe}$ of different dietary constituents and divalent metal transporter 1 will determine whether the Fe is transported into the cell or remains in the gut lumen. Recent research has shown that duodenal cytochrome $\mathrm{b}$ is responsible for reducing $\mathrm{Fe}^{3+}$ to $\mathrm{Fe}^{2+}$ (McKie et al. 2001); the main role of ascorbic acid is therefore to promote $\mathrm{Fe}$ solubility. Binding constants of dietary components and gastrointestinal conditions will determine how much $\mathrm{Fe}$ is released from chyme and the compounds to which it is bound. Any free Fe released from food by gastric acid will precipitate as insoluble oxide or hydroxide when the $\mathrm{pH}$ rises above $4-5$ in the duodenum or stomach of individuals with achlorhydria.

The absorption of $\mathrm{Fe}$ from meat is higher than that from plant foods (Bjorn-Rasmussen et al. 1974) because haem-Fe is absorbed more efficiently than non-haem-Fe (Hallberg et al. 1997) and non-milk animal proteins enhance nonhaem-Fe absorption (Cook \& Monsen, 1976; Glahn et al. 1996). The 'meat factor' has yet to be identified, but candidates include protein, cysteine-containing peptides or oligo-saccharides (Layrisse et al. 1984; Swain et al. 2002; Huh et al. 2004). However, the observation that meat solubilises non-haem-Fe independent of proteolytic digestion (Carpenter \& Mahoney, 1989) suggests that peptides are not the active component.

Ascorbic acid increases Fe absorption from meals; the increase in $\mathrm{Fe}$ absorption is directly proportional to the amount of ascorbic acid added over a range of $25-1000 \mathrm{mg}$ (Cook \& Monsen, 1977). The reducing and chelating properties of ascorbic acid are one reason why fruits and fruit juices (Hallberg \& Rossander, 1984; Ballot et al. 1987) promote $\mathrm{Fe}$ absorption from meals. Other organic acids such as lactic acid (Gillooly et al. 1983) enhance Fe absorption, but citric acid has been reported to have a limited (Ballot et al. 1987) or even an inhibitory effect (Hallberg \& Rossander, 1984). Ascorbic acid supplements $(500 \mathrm{mg})$ given three times daily with meals for 5.5 weeks improve the $\mathrm{Fe}$ status of $\mathrm{Fe}$-depleted premenopausal women (Hunt et al. 1990).

Polyphenols inhibit Fe absorption by binding with $\mathrm{Fe}$ in the gut lumen. The active principal is the galloyl group found in tannic and gallic acids, but not present in chlorogenic 
acid (Brune et al. 1989). Fe absorption is reduced by foods containing these compounds, including tea (Hurrell et al. 1999), coffee (Disler et al. 1975; Morck et al. 1983) and nuts (Macfarlane et al. 1988). Phytate (myo-inositol hexaphosphate) also has a powerful inhibitory effect on Fe absorption (Brune et al. 1992). This effect is counteracted by ascorbic acid but not greatly affected by the consumption of meat (Hallberg et al. 1989). When foods are processed by soaking, malting or fermenting the effect of phytate is reduced (Hurrell et al. 2003), although extensive degradation is necessary before $\mathrm{Fe}$ bioavailability is improved (Hurrell et al. 2002). The inhibitory effect of phytate can only be predicted by measuring individual inositol phosphates, as inositol hexaphosphate to inositol tetraphosphate, but not inositol triphosphate to inositol monophosphate, have Fe-binding activity (Sandberg et al. 1999). The inhibitory effect of soyabean (Derman et al. 1987) and other legumes (Lynch et al. 1984) is almost certainly a result of their phytate content.

$\mathrm{Ca}$ (threshold $50 \mathrm{mg}$ ) has been shown to reduce nonhaem-Fe absorption in a dose-dependent manner (Hallberg $\&$ Hulthen, 2000). Since it reduces haem-Fe absorption (Hallberg et al. 1993), and haem-Fe is transported independently into the mucosal cell, it is likely that $\mathrm{Ca}$ affects basolateral transport of Fe.

Predictive algorithms have also been developed to calculate Fe bioavailability from different diets, taking into account the major dietary factors that modulate Fe absorption (Hallberg \& Hulthen, 2000; Reddy et al. 2000).

\section{Interactions and adaptive responses}

Single-meal studies have highlighted the very real and often dramatic effects that certain dietary constituents have on $\mathrm{Fe}$ absorption. However, findings from longer-term intervention, cross-sectional and prospective studies do not always support findings from single-meal studies. The reason for this inconsistency is that adaptive responses in absorption take place to maintain Fe homeostasis. Thus, when exposed to a meal of low $\mathrm{Fe}$ bioavailability, the efficiency of absorption will be subsequently up regulated to compensate for the reduced supply of Fe, and absorption of Fe from the next meal will be enhanced. This adaptation results in an apparent exaggeration of the effect of inhibitors and enhancers in single-meal studies, as illustrated by Cook et al. (1991). However, single-meal studies do not, in fact, influence the effect of dietary factors per se, although prolonged fasting is probably unusual given today's dietary patterns, and may result in higher $\mathrm{Fe}$ absorption values as a result of the absence of chyme and reduced exposure to $\mathrm{Fe}$ in the mucosal absorptive cells. Single-meal protocols cannot measure compensatory adaptation (a function of both the diet and the host) but multiple-dosing protocols more closely mirror the situation in free-living individuals, with a blunted response to dietary enhancers and inhibitors (Tidehag et al. 1996).

\section{Dietary patterns and iron nutrition}

Epidemiological studies investigating the effects of diet on Fe status have produced inconsistent findings. As already discussed, there may be difficulties and/or inaccuracies in the determination of Fe status. The next challenge is the measurement of habitual $\mathrm{Fe}$ intake, because $\mathrm{Fe}$ status is a function of $\mathrm{Fe}$ supplied (and lost) over the past months or years. Total Fe intake is of limited value; indeed, an estimate of available $\mathrm{Fe}$ is required, and this measure can only be calculated from meal-based data, such as the validated questionnaire developed by Heath et al. (2000) to measure intake of Fe and key enhancers and inhibitors of absorption in meals (Matthys et al. 2004). Such an approach makes it possible to relate diet to measures of Fe status. The NDNS report Fe intakes on a daily basis, determined from a specially-adapted and regularly-updated nutrient databank based on McCance \& Widdowson's The Composition of Foods (Holland et al. 1991). Available Fe cannot be estimated from the NDNS reports, although the most recent survey of adults has collected meal-based data that could be analysed appropriately. However, more data on the phytate, polyphenol and haem-Fe contents of foods are required, and the calculated values will only be an approximation because of variance from food composition data, e.g. losses of ascorbic acid on storage and cooking, hydrolysis of phytate, etc. Another problem exists with Fe-fortified foods that can generate large errors in calculated Fe intake because of overages in products.

Despite all the problems associated with estimating available Fe intake, a number of observations on Fe status and dietary patterns can be deduced from cross-sectional epidemiological studies that have been conducted in other countries. The US Framingham Heart Study of 634 healthy free-living elderly subjects (Fleming et al. 1998) has reported that haem-Fe, dietary vitamin $\mathrm{C}$, alcohol and $\mathrm{Fe}$ supplements are all positively associated with SF, whereas

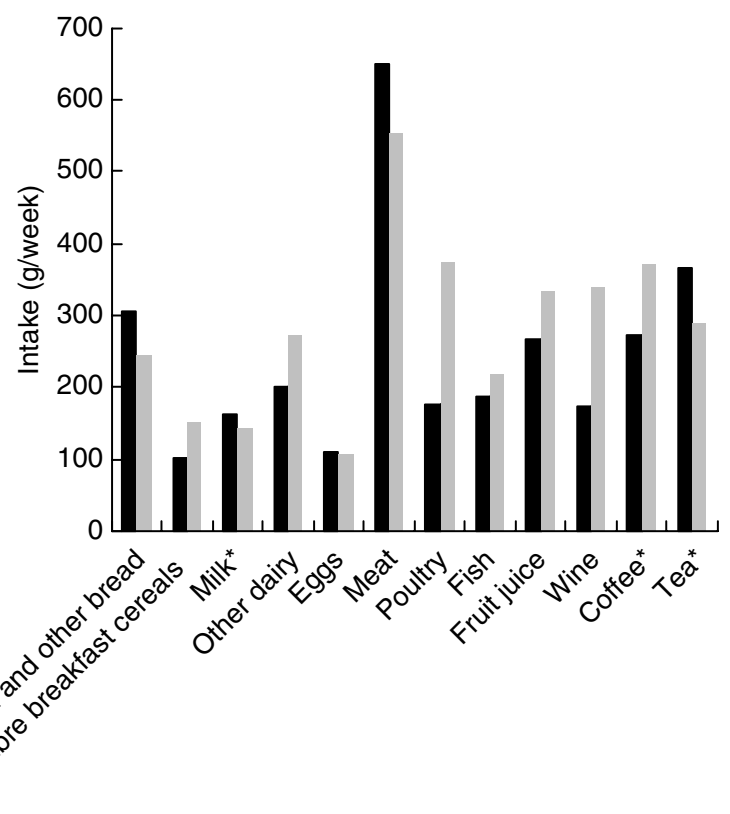

Fig. 6. National Diet and Nutrition Survey of adults 1986-7 ( $\boldsymbol{\square}$; Gregory et al. 1990) and 2000-1 ( $\square$; Henderson et al. 2002); a comparison of intakes of foods ( $\mathrm{g} /$ week) that may have an impact on iron nutrition. ${ }^{*}$ Values are shown as intake $\times 10^{-1}$. 
coffee intake has a negative association. In 1108 French subjects (aged 6 months-97 years) SF has been found to be positively correlated with haem- and non-haem-Fe intakes, and negatively correlated with $\mathrm{Ca}$ and $\mathrm{P}$ intakes (Preziosi et al. 1994). A larger French study (6648 women aged 35-60 years, and 3283 men aged 45-60 years) has reported that SF is positively correlated with meat, fish and total Fe intake, and negatively correlated with dairy products, Ca and fibre intake (Galan et al. 1998).

Further analysis of the NDNS of the elderly has found that $\mathrm{Fe}$ status is positively associated with meat, poultry and fish, but negatively associated with dairy foods, $\mathrm{Ca}$ and tea (Doyle et al. 1999). In contrast, a systematic review of sixteen studies on tea and Fe status, with adjustment for confounding factors, has concluded that tea consumption does not influence $\mathrm{Fe}$ status in Fe-replete Western populations, but there may be a negative association in populations with marginal $\mathrm{Fe}$ status (Temme \& Van Hoydonck, 2002). The impact of $\mathrm{Ca}$ on $\mathrm{Fe}$ status is both important and controversial. Dairy foods are a key food group for bone health, as well as providing protein for lacto-ovo-vegetarians, thus public health messages to reduce milk and dairy food intake in order to reduce the risk of Fe deficiency (Hallberg et al. 1992) may have a detrimental effect on other health outcomes. A crosssectional study in six European countries has demonstrated a weak but consistent inverse association between $\mathrm{Ca}$ intake and SF (van de Vijver et al. 1999), but the relationship was not found to be dependent on simultaneous ingestion of $\mathrm{Ca}$ and $\mathrm{Fe}$, nor was a dose-response effect observed. Most intervention studies have shown no effect of $\mathrm{Ca}$ on Fe nutrition. Reddy \& Cook (1997) have found that $\mathrm{Ca}$ intake has no effect on non-haem-Fe absorption from a varied diet over $5 \mathrm{~d}$, and other dietary interventions with $\mathrm{Ca}$ do not generally confirm the results from singlemeal studies (Sokoll \& Dawson-Hughes, 1992; Minihane \& Fairweather-Tait, 1998).

Trends in dietary patterns in the UK from the National Food Survey include a fall in the intakes of red meat and tea and an increase in fruit juice consumption (Heath \& Fairweather-Tait, 2002). Studies in vegetarians confirm that meat is a useful source of available Fe, as vegetarians generally have a lower SF concentration (WorthingtonRoberts et al. 1988; Alexander et al. 1994; Ball \& Bartlett, 1999), but $\mathrm{Fe}$ stores in many women of childbearing age, whether they are vegetarian or not (Donovan \& Gibson, 1995), appear to be low. In the NDNS of adults (Gregory et al. 1990) $14 \%$ of all women had a SF concentration of $<13 \mu \mathrm{g} / \mathrm{l}$, the highest percentage (21) being found in the 35-49 years age-group. Intakes of foods that may impact on Fe nutrition are compared for the 1986-7 and 2000-1 NDNS in Fig. 6. The fall in wholemeal and other breads is offset by the increase in high-fibre breakfast cereals, some of which are fortified with Fe, but they are consumed by only $48 \%$ of the respondents (Henderson et al. 2002). Meat (beef, lamb, pork, ham and bacon) intake has fallen and poultry intake has increased; $5 \%$ of respondents in the 2000-1 survey reported that they were vegetarian. Tea consumption is lower but coffee intake has risen, so the net effect on Fe availability is probably zero. Wine consumption has doubled, but the enhancing effect of alcohol is offset by the inhibitory effect of wine phenolics. There has been a slight increase in $\mathrm{Ca}$ intake and a more marked increase in vitamin $\mathrm{C}$ intake, but the latter only increases $\mathrm{Fe}$ absorption when consumed with main Fe-containing meals.

In order to evaluate the effect of diet on Fe status, further analysis of NDNS data is required, on a meal-bymeal basis, focused on the groups at risk of Fe deficiency (which might include infants and children, women of childbearing age, pregnant and lactating women and ethnic groups) or overload (men aged $\geq 40$ years). Dietary effects can be ascertained from measures of $\mathrm{Fe}$ status, including $\mathrm{Hb}, \mathrm{SF}$ (excluding high values resulting from infection or inflammation) and TS. In order to examine the relationship between diet and Fe status (perhaps concentrating on the upper and lower quintiles of $\mathrm{Fe}$ status), the nutrient databank requires expanding to incorporate information on the phytate, polyphenol, and haem-Fe contents of the UK diet. Dietary recommendations should be developed for vulnerable groups, taking into consideration the falling energy requirement, and thus the need to increase $\mathrm{Fe}$ density and availability in the diet. A simple self-screening method for high menstrual blood loss is required to identify women at risk of Fe-deficiency anaemia, both for use in the NDNS and for preventative medicine in primary care. Until UK dietary patterns change substantially, the main public health concern lies with $\mathrm{Fe}$ deficiency rather than Fe excess.

\section{Acknowledgments}

The author is funded by the Biotechnology and Biological Sciences Research Council. Linda Harvey provided Fig. 5 from data obtained in a project funded by the Food Standards Agency.

\section{References}

Alexander D, Ball MJ \& Mann J (1994) Nutrient intake and haematological status of vegetarians and age-sex matched omnivores. European Journal of Clinical Nutrition 48, 538-546.

Ball MJ \& Bartlett MA (1999) Dietary intake and iron status of Australian vegetarian women. American Journal of Clinical Nutrition 70, 353-358.

Ballot D, Baynes RD, Bothwell TH, Gillooly M, MacFarlane BJ, MacPhail AP et al. (1987) The effects of fruit juices and fruits on the absorption of iron from a rice meal. British Journal of Nutrition 57, 331-343.

Barrett JFR, Whittaker PG, Williams JG \& Lind T (1994) Absorption of non-haem iron from food during normal pregnancy. British Medical Journal 309, 79-82.

Bates CJ, Thurnham DJ, Bingham SA, Margetts BM \& Nelson M (1997) Biochemical markers of nutrient intake. In Design Concepts in Nutritional Epidemiology, 2nd ed., pp. 70-240 [BM Margetts and M Nelson, editors]. Oxford: Oxford University Press.

Baynes RD, Bothwell TH, Bezwoda WR, MacPhail AP \& Derman DP (1987) Relationship between absorption of inorganic and food iron in field studies. Annals of Nutrition and Metabolism 31, 109-116. 
Beshara S, Sörenson J, Lubberink M, Tolmachev V, Långström B, Antoni G, Danielson B \& Lundqvist H (2003) Pharmacokinetics and red cell utilization of ${ }^{52} \mathrm{Fe} /{ }^{59} \mathrm{Fe}$-labelled iron polymaltose in anaemic patients using positron emission tomography. British Journal of Haematology 120, 853-859.

Beutler E, Hoffbrand AV \& Cook JD (2003) Hematology (American Society of Hematology) 1, 40-61.

Bezwoda W, Charlton R, Bothwell T, Torrance J \& Mayet $\mathrm{F}$ (1978) Gastric hydrochloric acid and iron absorption. Journal of Laboratory and Clinical Medicine 92, 108-116.

Bjorn-Rasmussen E, Hallberg L, Isaksson B \& Arridsson B (1974) Application of the two-pool extrinsic tag method to measure haem and non-haem iron absorption from the whole diet. Journal of Clinical Investigation 53, 247-255.

Borel MJ, Smith SM, Derr J \& Beard J (1992) Day-to-day variation in iron-status indices in healthy men and women. American Journal of Clinical Nutrition 55, 729-735.

Bothwell TH, Charlton RW, Cook JD \& Finch CA (1979) Iron Metabolism in Man. London: Blackwell Scientific Publications.

Brune M, Rossander L \& Hallberg L (1989) Iron absorption and phenolic compounds: importance of different phenolic structures. European Journal of Clinical Nutrition 43, 547-558.

Brune M, Rossander-Hulthen L, Hallberg L, Gleerup A \& Sandberg AS (1992) Iron absorption from bread in humans: inhibiting effects of cereal fiber, phytate and inositol phosphates with different numbers of phosphate groups. Journal of Nutrition 122, 442-449.

Burt MJ, George PM, Upton JD, Collett JA, Frampton CM, Chapman TM, Walmsley TA \& Chapman BA (1998) The significance of haemochromatosis gene mutations in the general population: implications for screening. Gut 43, 830-836.

Calvin J, Neale G, Fotherby KJ \& Price CP (1988) The relative merits of acute phase proteins in the recognition of inflammatory conditions. Annals of Clinical Biochemistry 25, 60-66.

Carpenter CE \& Mahoney AW (1989) Proteolytic digestion of meat is not necessary for iron solubilization. Journal of Nutrition 119, 1418-1422.

Cook JD, Dassenko SA \& Lynch SR (1991) Assessment of the role of nonheme-iron availability in iron balance. American Journal of Clinical Nutrition 54, 717-722.

Cook JD, Flowers CH \& Skikne BS (2003) The quantitative assessment of body iron. Blood 101, 3359-3364.

Cook JD \& Monsen ER (1976) Food iron absorption. I. Use of semisynthetic diet to study absorption of nonheme iron. American Journal of Clinical Nutrition 28, 1289-1295.

Cook JD \& Monsen ER (1977) Vitamin C, the common cold, and iron absorption. American Journal of Clinical Nutrition 30, 235-241.

Dacie JV \& Lewis SM (1995) Practical Haematology, 8th ed. Edinburgh: Churchill Livingstone.

Derman DP, Ballot D, Bothwell TH, Macfarlane BJ, Baynes RD, Macphail AP, Gillooly M, Bothwell JE, Bezwoda WR \& Mayet F (1987) Factors influencing the absorption of iron from soya-bean protein products. British Journal of Nutrition 57, 345-353.

Disler PB, Lynch SR, Charlton RW, Torrance JD, Bothwell TH, Walker RB \& Mayet F (1975) The effect of tea on iron absorption. Gut 16, 193-200.

Donovan UM \& Gibson RS (1995) Iron and zinc status of young women aged 14 to 19 years consuming vegetarian and omnivorous diets. Journal of the American College of Nutrition 14, 463-472.

Doyle W, Crawley H, Robert H \& Bates CJ (1999) Iron deficiency in older people: interactions between food and nutrient intakes with biochemical measures of iron; further analysis of the National Diet and Nutrition Survey of people aged 65 years and over. European Journal of Clinical Nutrition 53, 552-559.

Finch CA, Deubelbeiss K, Cook JD, Eschbach JW, Harker LA, Funk DD, Marsaglia G, Hillman RS, Slichter S, Adamson JW, Ganzoni A \& Biblett ER (1970) Ferrokinetics in man. Medicine (Baltimore) 49, 17-53.

Finch S, Doyle W, Lowe C, Bates CJ, Prentice A, Smithers G \& Clarke PC (1998) National Diet and Nutrition Survey: People Aged 65 Years and Over. London: The Stationery Office.

Fleming DJ, Jacques PF, Dallal GE, Tucker KL, Wilson PWF \& Wood RJ (1998) Dietary determinants of iron stores in a free-living elderly population: The Framingham Heart Study. American Journal of Clinical Nutrition 67, 722-733.

Fox TE, Eagles J \& Fairweather-Tait SJ (1998) Bioavailability of iron glycine as a fortificant in infant foods. American Journal of Clinical Nutrition 67, 664-668.

Frazer DM, Wilkins SJ, Becker EM, Murphy TL, Vulpe CD, McKie AT \& Anderson GJ (2003) A rapid decrease in the expression of DMT1 and Dcytb but not Ireg1 or hephaestin explains the mucosal block phenomenon of iron absorption. Gut 52, 340-346.

Galan P, Yoon HC, Preziosi P, Viteri F, Valeix P, Fieux B, Briancon S, Malvy D, Roussel AM, Favier A \& Hercberg S (1998) Determining factors in the iron status of adult women in the SU.VI.MAX study. Supplementation en VItamines et Mineraux AntioXydants. European Journal of Clinical Nutrition 52, 383-388.

Gillooly M, Bothwell TH, Torrance JD, MacPhail AP, Derman DP, Bezwoda WR, Mills W, Charlton RW \& Mayet F (1983) The effects of organic acids, phytates and polyphenols on the absorption of iron from vegetables. British Journal of Nutrition 49, 331-342.

Glahn RP, Wien EM, Van Campen DR \& Miller DD (1996) Caco-2 cell iron uptake from meat and casein digests parallels in vivo studies: use of a novel in vitro method for rapid estimation of iron bioavailability. Journal of Nutrition 126, 332-339.

Gregory J, Foster K, Tyler H \& Wiseman M (1990) The Dietary and Nutritional Survey of British Adults. London: H. M. Stationery Office.

Gregory J, Lowe S, Bates CJ, Prentice A, Jackson LV, Smithers G, Wenlock R \& Farron M (2000) National Diet and Nutrition Survey: Young People Aged 4 to 18 Years. London: The Stationery Office.

Guillygomarc'h A, Christian J, Romain M, Vincnet Q, Veronique D \& Deugnier Y (2003) Circadian variations of transferrin saturation levels in iron-overloaded patients: implications for the screening of $\mathrm{C} 282 \mathrm{Y}$-linked haemochromatosis. British Journal of Haematology 120, 359-363.

Hallberg L, Brune M \& Rossander L (1989) Iron absorption in man: ascorbic acid and dose-dependent inhibition by phytate. American Journal of Clinical Nutrition 49, 140-144.

Hallberg L \& Hulthen L (2000) Prediction of dietary iron absorption: an algorithm for calculating absorption and bioavailability of dietary iron. American Journal of Clinical Nutrition 71, 1147-1160.

Hallberg L \& Hulthen L (2002) Perspectives on iron absorption. Blood Cells, Molecules and Diseases 29, 562-573.

Hallberg L, Hulthen L \& Gramatkovski E (1997) Iron absorption from the whole diet in men: how effective is the regulation of iron absorption? American Journal of Clinical Nutrition 66, 347-356.

Hallberg L \& Rossander L (1984) Improvement of iron nutrition in developing countries: comparison of adding meat, soy protein, ascorbic acid, citric acid, and ferrous sulphate on iron absorption from a simple Latin American-type of meal. American Journal of Clinical Nutrition 39, 577-583. 
Hallberg L, Rossander-Hulthen L, Brune M \& Gleerup A (1992) Calcium and iron absorption: mechanism of action and nutritional importance. European Journal of Clinical Nutrition 46, 317-327.

Hallberg L, Rossander-Hulthen L, Brune M \& Gleerup A (1993) Inhibition of haem-iron absorption in man by calcium. British Journal of Nutrition 69, 533-540.

Heath ALM \& Fairweather-Tait SJ (2002) Clinical implications of changes in the modern diet: iron intake, absorption and status. Best Practice and Research Clinical Haematology 15, 225-241.

Heath AL \& Fairweather-Tait SJ (2003) Health implications of iron overload: the role of diet and genotype. Nutrition Reviews 61, 45-62.

Heath A-LM, Skeaff CM \& Gibson RS (2000) The relative validity of a computerized food frequency questionnaire for estimating intake of dietary iron and its absorption modifiers. European Journal of Clinical Nutrition 54, 592-599.

Henderson L, Gregory J \& Swan G (2002) The National Diet and Nutrition Survey: Adults Aged 19 to 64 Years. Types and Quantities of Foods Consumed. London: The Stationery Office.

Holland B, Welch AA, Unwin ID, Buss DH, Paul AA \& Southgate DAT (1991) McCance and Widdowson's The Composition of Foods. 5th ed. Cambridge: Royal Society of Chemistry and MAFF.

Huh EC, Hotchkiss A, Brouillette J \& Glahn RP (2004) Carbohydrate fractions from cooked fish promote iron uptake by Caco-2 cells. Journal of Nutrition 134, 1681-1689.

Hulthen L, Lindstedt G, Lundberg P-A \& Hallberg L (1998) Effect of mild infection on serum ferritin concentration clinical and epidemiological implications. European Journal of Clinical Nutrition 52, 376-379.

Hunt JR, Mullen LM, Lykken GI, Gallagher SK \& Nielsen FH (1990) Ascorbic acid: effect on ongoing iron absorption and status in iron-depleted young women. American Journal of Clinical Nutrition 51, 649-655.

Hurrell RF, Reddy MB, Burri J \& Cook JD (2002) Phytate degradation determines the effect of industrial processing and home cooking on iron absorption from cereal-based foods. British Journal of Nutrition 88, 117-123.

Hurrell RF, Reddy M \& Cook JD (1999) Inhibition of non-haem iron absorption in man by polyphenolic-containing beverages. British Journal of Nutrition 81, 289-295.

Hurrell RF, Reddy MB, Juillerat M-A \& Cook JD (2003) Degradation of phytic acid in cereal porridges improves iron absorption by human subjects. American Journal of Clinical Nutrition 77, 1213-1219.

Jackson HA, Carter K, Darke C, Guttridge MG, Ravine D, Hutton RD, Napier JA \& Worwood M (2001) HFE mutations, iron deficiency and overload in 10,500 blood donors. British Journal of Haematology 114, 474-484.

Jacobs A \& Miles PM (1970) The formation of iron complexes with bile and bile constituents. Gut 11, 732-734.

Kuhn IN, Monsen ER, Cook JD \& Finch CA (1968) Iron absorption in man. Journal of Laboratory and Clinical Medicine 71, 715-721.

Labbe RF, Vreman HJ \& Stevenson DK (1999) Zinc protoporphyrin: a metabolite with a mission. Clinical Chemistry 45, 2060-2072.

Layrisse M, Martinez-Torres C, Leets I, Taylor P \& Ramirez J (1984) Effect of histidine, cysteine, glutathione or beef on iron absorption in humans. Journal of Nutrition 114, 217-223.

Lee CJ, Lawler GS \& Panemangalore M (1987) Nutritional status of middle-aged and elderly females in Kentucky in two seasons: Part 2. Hematological parameters. Journal of the American College of Nutrition 6, 217-222.
Leong W-I \& Lonnerdal B (2004) Hepcidin, the recently identified peptide that appears to regulate iron absorption. Journal of Nutrition 134, 1-4.

Lynch SR, Beard JL, Dassenko SA \& Cook JD (1984) Iron absorption from legumes in humans. American Journal of Clinical Nutrition 40, 42-47.

Lynch SR, Skikne BS \& Cook JD (1989) Food iron absorption in idiopathic hemochromatosis. Blood 74, 2187-2193.

McKie AT, Barrow D, Latunde-Dada GO, Rolfs A, Sager G, Mudaly E et al. (2001) An iron-regulated ferric reductase associated with the absorption of dietary iron. Science $\mathbf{2 9 1}$ 1755-1759.

Macfarlane BJ, Bezwoda WR, Bothwell TH, Baynes RD, Bothwell JE, MacPhail AP, Lamparelli RD \& Mayet F (1988) Inhibitory effect of nuts on iron absorption. American Journal of Clinical Nutrition 47, 270-274.

Mattys C, Pynaert I, Roe M, Fairweather-Tait SJ, Heath A-LM \& De Heanauw S (2004) Validity and reproducibility of a computerised tool for assessing the iron, calcium and vitamin $\mathrm{C}$ intake of Belgian women. European Journal of Clinical Nutrition (advance online publication).

Minihane AM \& Fairweather-Tait SJ (1998) Effect of calcium supplementation on daily nonheme-iron absorption and longterm iron status. American Journal of Clinical Nutrition $\mathbf{6 8}$, 96-102.

Miret S, Simpson RJ \& McKie AT (2003) Physiology and molecular biology of dietary iron absorption. Annual Reviews of Nutrition 23, 283-301.

Morck TA, Lynch SR \& Cook JD (1983) Inhibition of food iron absorption by coffee. American Journal of Clinical Nutrition 37, 416-420.

Murphy S, Curran MD, McDougall N, Callender ME, O'Brien CJ \& Middleton D (1998) High incidence of the Cys 282 Tyr mutation in the HFE gene in the Irish population - implications for haemochromatosis. Tissue Antigens 52, 484-488.

O'Neil-Cutting MA \& Crosby WH (1987) Blocking of iron absorption by a preliminary oral dose of iron. Archives of Internal Medicine 147, 489-491.

Oski FA (1993) Iron deficiency in infancy and childhood. New England Journal of Medicine 329, 190-193.

Pan WH \& Habicht JP (1991) The non-iron-deficiency-related difference in haemoglobin concentration distribution between blacks and whites and between men and women. American Journal of Epidemiology 134, 1410-1416.

Preziosi P, Hercberg S, Galan P, Devanlay M, Cherouvrier F \& Dupin H (1994) Iron status of a healthy French population: factors determining biochemical markers. Annals of Nutrition and Metabolism 38, 192-202.

Prynne CJ, Paul AA, Price GM, Day KC, Hilder WS \& Wadsworth MEJ (1999) Food and nutrient intake of a national sample of 4-year-old children in 1950: comparison with the 1990's. Public Health Nutrition 2, 537-547.

Punnonen K, Irjala K \& Rajamaki A (1997) Serum transferrin receptor and its ratio to serum ferritin in the diagnosis of iron deficiency. Blood 89, 1052-1057.

Reddy MB \& Cook JD (1997) Effect of calcium intake on nonheme-iron absorption from a complete diet. American Journal of Clinical Nutrition 65, 1820-1825.

Reddy MB, Hurrell RF \& Cook JD (2000) Estimation of nonheme-iron bioavailability from meal composition. American Journal of Clinical Nutrition 71, 937-943.

Ruston D, Hoare J, Henderson L, Gregory J, Bates CJ, Prentice A, Birch M, Swan G \& Farron M (2004) The National Diet and Nutrition Survey: Adults Aged 19 to 64 Years. London: The Stationery Office.

Sandberg A-S, Brune M, Carlsson N-G, Hallberg L, Skoglund E \& Rossander-Hulthen L (1999) Inositol phosphates with 
different numbers of phosphate groups influence iron absorption in humans. American Journal of Clinical Nutrition 70, 240-246.

Skikne B \& Baynes RD (1994) Iron absorption. In Iron Metabolism in Health and Disease, p. 177 [JH Brock, JW Halliday, MJ Pippard and LW Powell, editors]. London: WB Saunders.

Skikne BS \& Cook JD (1992) Effect of enhanced erythropoiesis on iron absorption. Journal of Laboratory and Clinical Medicine 20, 746-751.

Sokoll LJ \& Dawson-Hughes B (1992) Calcium supplementation and plasma ferritin concentrations in premenopausal women. American Journal of Clinical Nutrition 56, 1045-1048.

Suominen P, Punnonen K, Rajamaki A \& Irjala K (1998) Serum transferrin receptor and transferrin receptor-ferritin index identify healthy subjects with subclinical iron deficits. Blood 92, 2934-2939.

Swain JH, Tabatabai LB \& Reddy MB (2002) Histidine content of low-molecular-weight beef proteins influences nonheme iron bioavailability in Caco-2 cells. Journal of Nutrition 132, 245-251.

Taylor PG, Mendez-Castellano H, Lopez-Blanco M, LandaetaJiminez M, Hernandez-Valera Y, Arenas O, Martinez-Torres C \& Layrisse M (1988) Daily physiological iron requirements in children. Journal of the American Dietetic Association 88, 454-458.

Temme EHM \& Van Hoydonck PGA (2002) Tea consumption and iron status. European Journal of Clinical Nutrition 56, 379-386.

Tidehag P, Hallmans G, Wing K, Sjostrom R, Agren G, Lundin E \& Zhang J-X (1996) A comparison of iron absorption from single meals and daily diets using radioFe $\left({ }^{55} \mathrm{Fe},{ }^{59} \mathrm{Fe}\right)$. British Journal of Nutrition 75, 281-289.

Tufts DA, Haas JD, Beard JL \& Spielvogel H (1985) Distribution of haemoglobin and functional consequences of anemia in adult males at high altitude. American Journal of Clinical Nutrition 42, 1-11.

van de Vijver LPL, Kardinaal AFM, Charzewska J, Rotily M, Charles P, Maggiolini M et al. (1999) Calcium intake is weakly but consistently negatively associated with iron status in girls and women in six European countries. Journal of Nutrition 129, 963-968.

Van Tiel ED, Peeter PHM, Smit HA, Nagelkerke NJD, Van Loon AJM, Grobbee DE \& Bueno-de-Mesquita HB (2002) Quitting smoking may restore haematological characteristics within five years. Annals of Epidemiology $\mathbf{1 2}$ 378-388.

Velati C, Marlianici E, Rigamonti D, Barillari G, Chiavilli F, Fugiani P et al. (2003) Mutations of the haemochromatosis gene in Italian candidate blood donors with increased transferrin saturation. Hematology Journal 4, 436-440.

Waalen J, Felitti V, Gelbart T, Ho NJ \& Beutler E (2002) Penetrance of haemochromatosis. Blood Cells, Molecules and Diseases 29, 418-432.

Walters GO, Miller FM \& Worwood M (1973) Serum ferritin concentration and iron stores in normal subjects. Journal of Clinical Pathology 26, 770-772.

Wintrobe MM (1981) Clinical Hematology, 8th ed. Philadelphia, PA: Lea \& Febiger.

World Health Organization/UNICEF/United Nations University (2001) Iron deficiency anaemia. Assessment, prevention and control. A guide for programme managers. WHO/UNICEF/UNU http://www.who.int/nut/documents/ida_assessment_prevention_ control.pdf

World Health Organization (1972) Nutritional Anaemias. WHO Technical Report Series no. 503. Geneva: WHO.

Worthington-Roberts BS, Breskin MW \& Monsen ER (1988) Iron status of premenopausal women in a university community and its relationship to habitual dietary sources of protein. American Journal of Clinical Nutrition 47, 275-279.

Yip R (2000) Significance of an abnormally low or high haemoglobin concentration during pregnancy: special consideration of iron nutrition. American Journal of Clinical Nutrition 72, 272S-279S.

Yip R, Johnson C \& Dallman PR (1984) Age-related changes in laboratory values used in the diagnosis of anemia and iron deficiency. American Journal of Clinical Nutrition 39, 427-436. 